\title{
Advanced Treatment of Salty Eutrophication Water Using Algal-Bacterial Granular Sludge: With Focus on Nitrogen Removal, Phosphorus Removal, and Lipid Accumulation
}

\author{
Fansheng Meng, ${ }^{a}$ Yu Liu, ${ }^{\mathrm{b}}$ Ping Zhang, ${ }^{\mathrm{c}}$ Dongfang Liu, ${ }^{\mathrm{a}, *}$ and Wenli Huang ${ }^{\mathrm{a}, *}$
}

\begin{abstract}
A new algal-bacterial granular sludge treatment method was used to treat salty eutrophication water. The results indicated that the treatment removed more than $98 \%$ of the total inorganic nitrogen and the total phosphorus after a 15 d cultivation period using $2 \%$ salinity simulated eutrophication water. For the $4 \%$ salinity simulated water, the total phosphorus was not able to be removed and was even higher in the effluent; and the total inorganic nitrogen was only removed $17 \%$. Thus, the algal-bacterial granules were efficient for removing nitrogen and phosphorus in $2 \%$ salinity eutrophication water but were not effective for $4 \%$ salinity water. High levels of filamentous algae proliferation growing on the surface of the granules was primarily responsible for the good performance in $2 \%$ salinity water. However, the lipid accumulation was greatly enhanced (reactor $\mathrm{R} 2$ at a $27.6 \%$ increase and reactor $\mathrm{R} 4$ at a $107 \%$ increase) for both granule types due to the algal growth. Thus, treatment of the salty eutrophication water can also greatly increase the added-value of the algal-bacterial granules.
\end{abstract}

Keywords: Salty eutrophication water; Algal-bacterial granular sludge; Nutrient removal; Algae; Lipid

Contact information: a: Tianjin Key Laboratory of Environmental Technology for Complex Trans-Media Pollution; College of Environmental Science and Engineering, Nankai University, Tianjin 300350, China; b: Tianjin Drainage Management Office, Tianjin 300202, China; c: Tianjin Water Authority, Tianjin 300074, China; Corresponding authors: *dongfangl@nankai.edu.cn; huangwenli@nankai.edu.cn

\section{INTRODUCTION}

Anthropogenic eutrophication in salty aquatic ecosystems is a worldwide problem that occurs in coastal areas or industrial districts (Xiong et al. 2016; McIver et al. 2018; Corrales-González et al. 2019; Katsuki et al. 2019). With the overproduction of salts and organic/inorganic nutrients from anthropogenic inputs into rivers, ditches, lagoons, and lakes, the eutrophication of saltwater bodies can be caused by low levels of residual nitrogen (N) and phosphorus (P) (Derolez et al. 2019; Longley et al. 2019; Yao et al. 2019; Zheng et al. 2019). The residues of $\mathrm{N}$ and $\mathrm{P}$ result in the proliferation of some opportunistic algal species, which can lead to the crisis of the ecosystem and extensive death of aquatic animals (Bhagowati and Ahamad 2018; McIver et al. 2018; VinçonLeite and Casenave 2019). In China, many urban zones in the Binhai New Area of Tianjin have a serious problem with the eutrophication of the saltwater bodies (Xiong et al. 2016). The ditches and small lakes in these areas often have a green color, as well as a foul smell and dead animals found in the water, which reduces the environmental health of nearby areas. 
Large quantities of nutrients $(\mathrm{N}$ and $\mathrm{P})$ in eutrophication water come from wastewater treatment plants (Hu et al. 2017; Bhagowati and Ahamad 2018). The typical threshold for $\mathrm{N}$ and $\mathrm{P}$ levels that cause eutrophication are $1.2 \mathrm{mg} / \mathrm{L}$ and $0.1 \mathrm{mg} / \mathrm{L}$, respectively (Chambers et al. 2012; Hu et al. 2017; Bhagowati and Ahamad 2018). However, the discharging limits for $\mathrm{N}$ and $\mathrm{P}$ from wastewater treatment plants are 10 $\mathrm{mg} / \mathrm{L}$ to $15 \mathrm{mg} / \mathrm{L}$ and $0.5 \mathrm{mg} / \mathrm{L}$ to $1 \mathrm{mg} / \mathrm{L}$ (Hu et al. 2017). Thus, the eutrophication process can be induced from these and other sources. The residual $\mathrm{N}$ and $\mathrm{P}$ are difficult to eliminate via traditional biological methods. The very limited organic nutrients in the water cannot provide sufficient carbon sources for bacterial growth (Hamza et al. 2019), and a high salinity level may cause the death of bacteria cells (Jorfi et al. 2017). Hence, the thorough removal of $\mathrm{N}$ and $\mathrm{P}$ is critical for the remediation of salty eutrophication water.

Algal-bacterial granular sludge is an innovative biotechnology that combines algae with aerobic granular sludge (AGS). This technology is efficient in removing $\mathrm{N}$ and $\mathrm{P}$ due to the assimilation of a large quantity of algae in the granules (Meng et al. 2019b; Zhao et al. 2019). In addition, it overcomes the difficulty of biomass harvest for algae because the AGS shows excellent settling ability. The algal-bacterial granules have a high biodiesel content, as many algal species are rich in lipids (Ishika et al. 2017; Liu et al. 2017). Meng et al. (2019a) successfully cultivated algal-bacterial granules in high salinity wastewater (1\% to 3\%). Meng et al. (2019a) reported that the algal-bacterial granules, as well as the algae inside, could withstand a high salinity environment and still was efficient in the removal of $\mathrm{N}$ and $\mathrm{P}$ in salty wastewater.

For eutrophication water, the bacteria have difficulty surviving, and the removal rate of $\mathrm{N}$ and $\mathrm{P}$ is low due to the limited nutrient levels. In contrast, some salt-tolerant algae continue to grow and assimilate $\mathrm{N}$ and $\mathrm{P}$ with the help of photosynthesis (Meng et al. 2019a). Thus, the algal-bacterial granules could have a strong potential for the removal of $\mathrm{N}$ and $\mathrm{P}$ when treating salty eutrophication water, due to its large algae content. The increased growth rate of the algae in the algal-bacterial granules could increase the biodiesel content during the eutrophication water treatment process (Blaas and Kroeze 2014; Vo Hoang Nhat et al. 2018; Meng et al. 2019b). Thus, the application of algal-bacterial granular sludge is promising for eutrophication water treatments. There have been no previous studies performed using algal-bacterial granules for the treatment of salty eutrophication water, and the relative information is sparse.

In the present study, an algal-bacterial granular sludge was used for the treatment of simulated salty eutrophication water. The morphology and characteristics of the algalbacterial granules were observed to better understand the mechanisms of the treatment process. The amount of nutrient removal ( $\mathrm{N}$ and $\mathrm{P}$ ) was monitored to evaluate the performance of the granules. The lipid production was monitored to determine the added value of the granules in the cultivation. This study provides meaningful reference for future salty eutrophication water treatment, with a new application of algal-bacterial granular sludge technology.

\section{EXPERIMENTAL}

\section{Reactor Design and Operation}

Two identical sequencing batch reactors $(\mathrm{SBR})(\mathrm{D} \times \mathrm{H}=6 \mathrm{~cm} \times 100 \mathrm{~cm})$ made of acrylic plastic were used for the experiments (Fig. S1). The effective working volume of 
each reactor was 2.0 L. Four $7 \mathrm{~W}$ white LED tubes (Opple, T5, Shanghai, China) were evenly distributed around each reactor at a $3 \mathrm{~cm}$ distance from the outer wall to provide light illuminance $\left(180 \mu \mathrm{mol} \mathrm{m} \mathrm{m}^{-2} \mathrm{~s}^{-1}\right)$. A large incubator was used to cover the reactors from external light sources. The operation ran for $12 \mathrm{~h}$ per cycle, including: $2 \mathrm{~min}$ of feeding, 2 min of non-aeration, $706 \mathrm{~min}$ of aeration, $5 \mathrm{~min}$ of settling, $3 \mathrm{~min}$ of decanting, and 2 min of idling. The room temperature was maintained at $23 \pm 2{ }^{\circ} \mathrm{C}$. The light was consistently provided for all of the cycles each day. An outlet port was set in the middle of each SBR. The volume exchange ratio was $50 \%$ and the hydraulic retention time (HRT) was $24 \mathrm{~h}$. Aeration was provided (3 L/min) from an air pump through an air stone at the bottom. The dissolved oxygen (DO) concentration was kept above $7 \mathrm{mg} / \mathrm{L}$ in the reactors.

\section{Seed Sludge and Simulated Eutrophication Water}

The seed algal-bacterial granular sludge was prepared according to Meng et al. (2019a). Granules were cultivated separately in $2 \%$ salinity and $4 \%$ salinity wastewater. After a $130 \mathrm{~d}$ cultivation period, the mature algal-bacterial granules were used as seed sludge for the treatment of the salty eutrophication water. Seed granules were put into two identical SBRs, with the initial mixed liquor suspended solids (MLSS) of the two SBRs set as $7.0 \mathrm{~g} / \mathrm{L}$.

A wastewater treatment plant is an important source for nutrients ( $\mathrm{N}$ and $\mathrm{P}$ ) to be added into eutrophication water. Thus, the synthesized salty eutrophication water was created according to the simulated wastewater methodology used by Meng et al. (2019a). The nutrient components in the wastewater were modified to a very low concentration in order to achieve a relative excess content of $\mathrm{N}$ and $\mathrm{P}$ (Chambers et al. 2012; Hu et al. 2017). The synthesized salty eutrophication water contained $0.5 \mathrm{mg} / \mathrm{L}$ of $\mathrm{PO}_{4}-\mathrm{P}$ $\left(\mathrm{KH}_{2} \mathrm{PO}_{4}\right), 7.5 \mathrm{mg} / \mathrm{L}$ of $\mathrm{NH}_{4}-\mathrm{N}\left(\left(\mathrm{NH}_{4}\right)_{2} \mathrm{SO}_{4}\right), 30 \mathrm{mg} / \mathrm{L}$ of COD (glucose $50 \%$ and sodium acetate $50 \%$ ), $30 \mathrm{mg} / \mathrm{L}$ of $\mathrm{NaHCO}_{3}, 3 \mathrm{mg} / \mathrm{L}$ of $\mathrm{CaCl}_{2}, 2.5 \mathrm{mg} / \mathrm{L}$ of $\mathrm{MgSO}_{4} \cdot 7 \mathrm{H}_{2} \mathrm{O}$, and 2 $\mathrm{mg} / \mathrm{L}$ of $\mathrm{FeSO}_{4} \cdot 7 \mathrm{H}_{2} \mathrm{O}$. However, the salinity levels of some rivers in the Binhai New Area of Tianjin were reported to be below 2.3\% salinity (Xiong et al. 2016). In addition, lakes or lagoons in some costal places could have a higher salinity level closer to seawater (3.5\% salinity) due to tidal intrusion. Therefore, two salinity levels, low (2\%) and high (4\%), were set for this study. The $\mathrm{NaCl}$ concentrations in the influent of the two reactors were kept at $20 \mathrm{~g} / \mathrm{L}$ ( $2 \%$ salinity) and $40 \mathrm{~g} / \mathrm{L}$ (4\% salinity), respectively. Namely, the two reactors were set as R2 and R4 according to their salinity level. The seed granules cultivated from the $2 \%$ salinity wastewater were put in R2, and the granules from the $4 \%$ salinity wastewater were put in R4. All the chemicals (AR grade) were purchased from Aladdin Industrial Corporation Ltd., Shanghai, China.

\section{Analytical Methods}

The total phosphorus (TP), nitrate nitrogen $\left(\mathrm{NO}_{3}-\mathrm{N}\right)$, nitrite nitrogen $\left(\mathrm{NO}_{2}-\mathrm{N}\right)$, ammonia nitrogen $\left(\mathrm{NH}_{4}-\mathrm{N}\right)$, sludge volume index $\left(\mathrm{SVI}_{30}\right)$, and mixed liquor (volatile) suspended solids (ML(V)SS) were measured by the standard methods (APHA 2012). The total inorganic nitrogen (TIN) was calculated with Eq. 1,

$$
[\mathrm{TIN}]=\left[\mathrm{NO}_{3}--\mathrm{N}\right]+\left[\mathrm{NO}_{2}--\mathrm{N}\right]+\left[\mathrm{NH}_{4}--\mathrm{N}\right]
$$

where TIN is the total inorganic nitrogen, $\mathrm{NO}_{3}-\mathrm{N}$ is the nitrate nitrogen amount, $\mathrm{NO}_{2}-\mathrm{-N}$ is the nitrite nitrogen amount, and $\mathrm{NH}_{4}-\mathrm{N}$ is the ammonia nitrogen amount. A dissolved oxygen (DO) meter (HQ40d, Hach, Loveland, CO, USA) was used to detect the DO 
concentration. The $\mathrm{pH}$ in the bulk liquid was measured with a $\mathrm{pH}$ meter (AS-711, AS ONE, Osaka, Japan) and kept between $7.0 \mathrm{pH}$ and $8.5 \mathrm{pH}$. The chlorophyll $a$ content in the granules was measured according to Zhang et al. (2018). The total lipid content was detected according to Meng et al. (2019b), and the light intensity was detected by a photometer (TES-1339, TES, Taipei, China). The morphology of the granules was observed with an optical microscope (CX40, Sunny, Yuyao, China) with a digital camera (700D, Canon, Tokyo, Japan) equipped on it. A scanning electron microscope (SEM) (FEI-Quanta 200, Thermo Fisher Scientific, Waltham, USA) was also used for the analysis of the morphology of the granules. The biological microbial community was detected according to Zhang et al. (2017) by a biotech testing company ALLWEGENE Inc. (Beijing, China). Statistical significance was calculated using one-way analysis of variance in Microsoft Office Excel 2010. The difference of results was announced statistically significant when the $p$ value $<0.05$.

\section{RESULTS AND DISCUSSION}

\section{Effects of Simulated Salty Eutrophication Water on the Characteristics of Algal-bacterial Granular Sludge}

The cultivation process in simulated salty eutrophication water could greatly influence the morphology and characteristics of algal-bacterial granules. However, the use of simulated eutrophication water with a low or a high salinity level had a different effect on the morphology and characteristics of the algal-bacterial granules. After a $15 \mathrm{~d}$ cultivation period in low (2\%) salinity eutrophication water, the MLSS in R2 showed an increase from $7.0 \mathrm{~g} / \mathrm{L}$ to $7.9 \mathrm{~g} / \mathrm{L}$, as shown in Table 1. In contrast, the MLSS in R4 (4\% salinity) greatly decreased from $7.0 \mathrm{~g} / \mathrm{L}$ to $2.8 \mathrm{~g} / \mathrm{L}$. The difference of MLSS between the two reactors on $15 \mathrm{~d}$ was significant $\left(p=7.0 \times 10^{-6}<0.05\right)$. The different change in biomass content could be due to the large difference in algae growth and stability of the two granular systems. The stability of the granules closely related to the filamentous algae growing on the surface of the granules in the two reactors. It was observed that some filamentous algae began to appear and tightly bind to the surface of the granules in $\mathrm{R} 2$ after $5 \mathrm{~d}$, as shown in Fig. 1. The algae became more abundant and covered the whole granule after $15 \mathrm{~d}$. However, for the high (4\%) salinity eutrophication water, a low amount of green algae was found on the surface of the granules in R4 after $15 \mathrm{~d}$. 


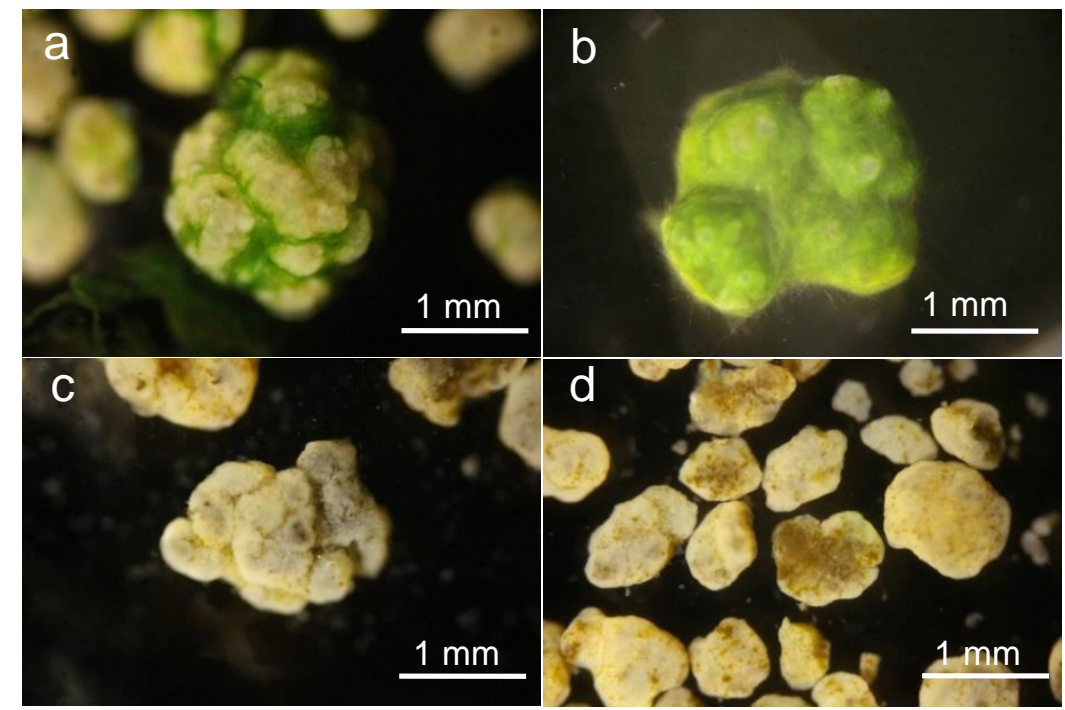

Fig. 1. Digital images of the algal-bacterial granules in $R 2$ at $5 d(a)$ and at $15 d$ (b), and in $R 4$ at $0 \mathrm{~d}(\mathrm{c})$ and at $15 \mathrm{~d}(\mathrm{~d})$, respectively

Table 1. Characteristics of Granules in the Reactors

\begin{tabular}{|c|c|c|c|c|}
\hline Parameters & $\mathbf{R 2}_{\mathbf{0}}$ & $\mathbf{R 2}_{15 \mathrm{~d}}$ & $\mathbf{R 4}_{\mathbf{0}} \mathbf{d}$ & $\mathbf{R 4}_{15 \mathrm{~d}}$ \\
\hline MLSS (g/L) & $7.0 \pm 0.1$ & $7.9 \pm 0.2$ & $7.0 \pm 0.2$ & $2.8 \pm 0.2$ \\
\hline MLVSS/MLSS SVI $_{30}(\mathrm{~mL} / \mathrm{g})$ & $0.88 \pm 0.01$ & $0.90 \pm 0.00$ & $0.88 \pm 0.01$ & $0.91 \pm 0.01$ \\
\hline Chlorophyll a $(\mathrm{mg} / \mathrm{g}(\mathrm{SS}))$ & $10.9 \pm 1.3$ & $19.6 \pm 1.7$ & $7.3 \pm 1.1$ & $14.2 \pm 1.4$ \\
\hline
\end{tabular}

High filamentous algae levels were important for the improvement of the stability of the algal-bacterial granules (Ahmad et al. 2017). As the nutrient levels in the simulated eutrophication water were insufficient for heterotrophic microorganism growth; the granular systems remained in endogenous respiration and were unstable, with the granules easily broken up. However, the filamentous algae in R2 improved the stability of the granules and protected them from losing their biomass into the effluent. On the contrary, the granules in R4 had limited filamentous algae on the surface. Therefore, the system showed an unstable status in the 15 d cultivation period with a large number of the granules breaking up and losing a majority of its biomass.

The total chlorophyll $a$ content was determined to indicate the total algae content in the granules for both of the reactors. After a $15 \mathrm{~d}$ cultivation period, the total chlorophyll $a$ in R2 increased from $3.2 \mathrm{mg} / \mathrm{g}$ (SS) to $8.5 \mathrm{mg} / \mathrm{g}$ (SS), while the chlorophyll $a$ in R4 only increased from $3.8 \mathrm{mg} / \mathrm{g}$ (SS) to $5.9 \mathrm{mg} / \mathrm{g}$ (SS). This showed that the algal content in R2 and R4 both greatly increased after the cultivation. However, the low salinity level water reactor (R2) finally had a much higher algal content than R4 ( $p=6.0$ $\times 10^{-6}<0.05$ ). The algae could have a negative effect on the settling ability of the granules. The $\mathrm{SVI}_{30}$ for $\mathrm{R} 2$ and $\mathrm{R} 4$ showed an increase from $10.9 \mathrm{~mL} / \mathrm{g}$ and $7.2 \mathrm{~mL} / \mathrm{g}$ at 0 $\mathrm{d}$ to $19.6 \mathrm{~mL} / \mathrm{g}$ and $14.2 \mathrm{~mL} / \mathrm{g}$ at $15 \mathrm{~d}$, respectively. The final settling ability was a little lower for granules in R2 $(p=0.013<0.05)$. However, the settling ability in the two reactors were still excellent due to maintenance of the $\mathrm{SVI}_{30}$ values at low levels. Moreover, a small increase in the MLVSS/MLSS ratio was found in both the reactors ( $p$ $=0.090>0.05$ ), which indicated the algae content might also improve the organic 
components in the granules. It is known that many algal species are rich in lipid content (Ishika et al. 2017; Meng et al. 2019a). Thus, the cultivated granules in R2 and R4 probably had a higher lipid production than the initial algal-bacterial granules.

\section{Overall Performance of Reactors for $\mathbf{N}$ and $\mathbf{P}$ Removal}

Total phosphorus and TIN removal levels in the two reactors are shown in Fig. 2. At $2 \mathrm{~d}$, the TP concentrations from the effluent in R 2 increased rapidly to $1.5 \mathrm{mg} / \mathrm{L}$ at $3 \mathrm{~d}$, much higher than the influent TP content $(0.5 \mathrm{mg} / \mathrm{L})$. This could be due to the inorganic nutrients, including $\mathrm{N}$ and $\mathrm{P}$, being released from the extracellular polymeric substance (EPS) or from bacteria cells into the water in the endogenous respiration (Zhang et al. 2016; Zhou et al. 2019). But the TP concentration began to decline afterwards and was nearly at $0 \mathrm{mg} / \mathrm{L}$ at $12 \mathrm{~d}$, achieving a removal efficiency of greater than $98 \%$. By comparison, the TP concentration in the effluent from R4 increased more slowly in the beginning and slowly declined after $6 \mathrm{~d}$. However, the final concentration after $14 \mathrm{~d}$ was approximately $0.7 \mathrm{mg} / \mathrm{L}$ in $\mathrm{R} 4$, still much higher than the influent. This indicated that the algal-bacterial granules in the $4 \%$ salinity eutrophication water were inefficient at the removal of phosphorus. A similar trend was also observed for the effluent TIN variation in the two reactors and the R4 still had a low TIN removal rate, approximately $17 \%$ at 14 d. However, the TIN concentration in R2 declined more quickly to $0 \mathrm{mg} / \mathrm{L}$ at $7 \mathrm{~d}$ with a removal efficiency of greater than $98 \%$.

(a)

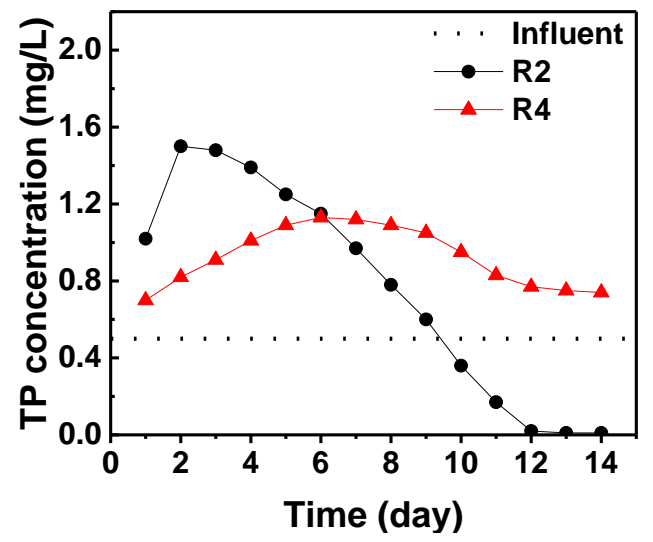

(b)

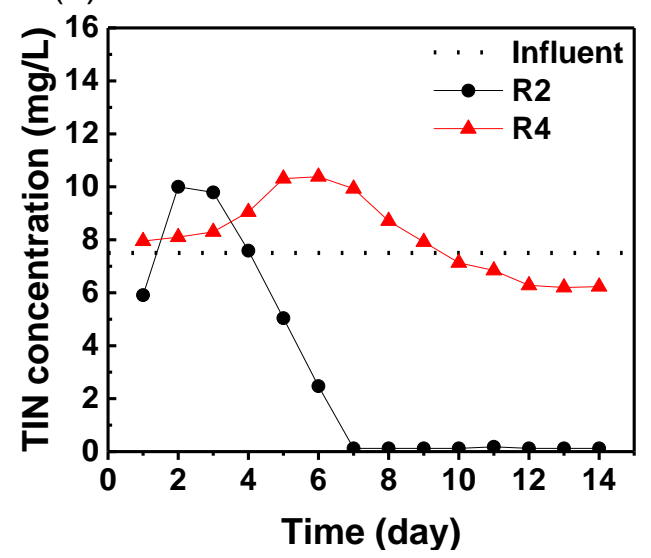

Fig. 2. Variations of TIN (a) and TP (b) removal during the operation

The algal-bacterial granules in $\mathrm{R} 2$ were able to efficiently remove the $\mathrm{N}$ and $\mathrm{P}$ nutrients after cultivation in $2 \%$ salinity eutrophication water. However, the granules in R4 did not seem fit to treat the $4 \%$ salinity eutrophication water. As the influent organic nutrients were quite low, the removal of the inorganic $\mathrm{N}$ and $\mathrm{P}$ could be mainly ascribed to the assimilation of the algae. The different performance between the two reactors might be due to the different algae content levels and their distribution between the granules.

The algal-bacterial granules in $\mathrm{R} 2$ had a greater algal content than R4, as shown in Table 1. In addition, the biological community structure analysis showed that the Cyanobacteria phylum dominated the prokaryote phyla present in the granules of R2, as shown in Fig. S2. The Nitzschia genus from the Bacillariophyta phylum dominated the eukaryote genera present in both R2 and R4. The Cyanobacteria phylum contains many 
types of filamentous algae, which are known to readily proliferate in eutrophication water (Anahas and Muralitharan 2018; Manolidi et al. 2019). It was observed that a large number of filamentous algae grew on the surface of the granules in R2, as shown in Fig. 1 and S3, most of which were Cyanobacteria. The filamentous algae quickly covered whole granules on the surface after several days of cultivation. They could assimilate the released $\mathrm{N}$ and $\mathrm{P}$ from the EPS and bacteria cells for their growth and prevent the nutrients from going into the bulk liquid. Thus, the effluent $\mathrm{N}$ and $\mathrm{P}$ levels quickly dropped with the algae growth. For the granules in R4, most of the algae (Nitzschia) were distributed in the inner part of the granules for the entire cultivation period, and bacteria were primarily located in the outer layer, as shown in Fig S3. Thus, large amounts of N and $\mathrm{P}$ from the EPS and bacteria cells were easily released into the water environment, which resulted in low removal efficiency.

\section{Effects of Simulated Salty Eutrophication Water on Lipid Production}

The changes in lipid content via the granules of R2 and R4 are described in Fig. 3. Lipid content in granules from R2 had a large increase from $50.7 \mathrm{mg} / \mathrm{g}$ (SS) to $64.7 \mathrm{mg} / \mathrm{g}$ (SS) after a $15 \mathrm{~d}$ cultivation period. A large improvement of $27.6 \%$ was observed for the lipid content. For the granules in R4, the lipid content had a more dramatic increase from $54.1 \mathrm{mg} / \mathrm{g}$ (SS) to $112.0 \mathrm{mg} / \mathrm{g}$ (SS). A higher improvement rate of $107.0 \%$ was obtained, with the lipid content more significantly motivated by $4 \%$ salinity $\left(p=1.1 \times 10^{-5}<\right.$ $0.05)$. Salty eutrophication water with low (2\%) and high salinities (4\%) both enhanced the lipid content in the algal-bacterial granules. The increase in lipid content could be mainly ascribed to the algae content increase in both of the reactors, as shown in Table 1. However, the different lipid content levels in the two reactors might be due to the fact that the algae species and the salinities were different.

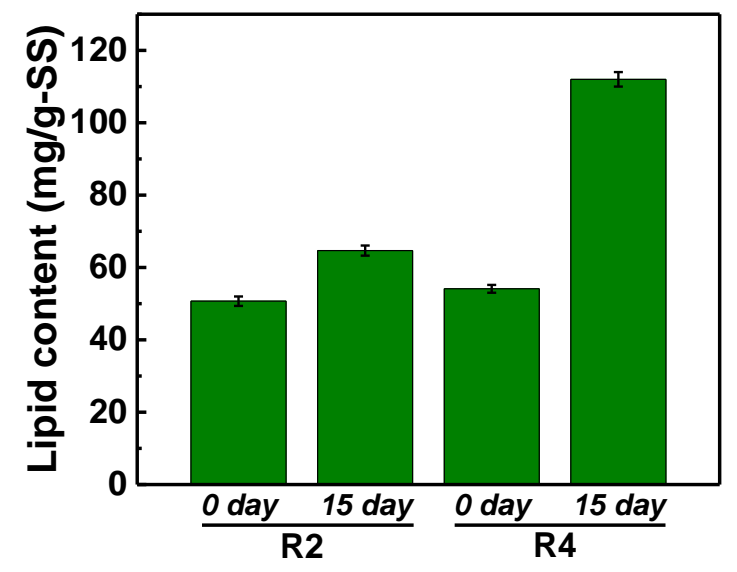

Fig. 3. Lipid content in the granules from the two reactors

As mentioned above, a large amount of filamentous algae from the Cyanobacteria phylum grew on the surface of the algal-bacterial granules in R2. However, the main algae genus in R4 was still Nitzschia, since limited filamentous algae was found in the granules. In addition, salinity was an important motivator for lipid production in Nitzschia. The Nitzschia was reported to possess a higher lipid content $(27.2 \%)$ when salinity levels reached 3\%, which was more abundant than when under no salt conditions 
(9.9\%) (Cheng et al. 2014). The lipid content in fifteen common algae species from the Cyanobacteria phylum were found to only vary from $5.9 \%$ to $18.9 \%$ (Anahas and Muralitharan 2018), which was much less than Nitzschia under 3\% salinity conditions. Therefore, the algal-bacterial granules in R4 had more lipid production than R2, which was probably due to the lipid content in Nitzschia being enhanced by the higher salinity level.

Currently, the waste biomass from the wastewater treatment plants in China is mainly disposed by sanitary landfill due to its low cost, but it may induce environmental problems (Yang et al. 2015). Other disposal methods are also used, including land application, incineration, and producing building materials (Yang et al. 2015). Meanwhile, energy reuses of the waste biomass have been explored, which include anaerobic digestion to biogas or extracting the lipid (Tyagi and Lo 2013; Bora et al. 2020; Luo et al. 2020). Microalgae are known to have relatively higher lipid content, and also they have the advantage of high growth rate, as well as a high ability to fix carbon dioxide (Shi et al. 2018). The lipid in microalgae was reported to be converted into jet fuel, indicating the big potential for industry use (Ju et al. 2018). Therefore, the lipid enhancement by algae increase in the algal-bacterial granules in the two reactors might be helpful for reusing the waste biomass as feedstock to biodiesel extraction.

\section{Summary of Algal-bacterial Granules for Salty Eutrophication Water Remediation at Different Salinity Levels}

The algal-bacterial granular sludge was shown to be effective for the removal of $\mathrm{N}$ and $\mathrm{P}$ under the treatment conditions of $2 \%$ salinity eutrophication water in the present study. Meanwhile, the lipid content also increased by approximately $27.6 \%$ during the cultivation process. This was quite beneficial for extracting biodiesel from the waste algal-bacterial granules. With both of these benefits, the algal-bacterial granules are quite useful for certain salinity eutrophication water treatment processes ( $2 \%$ salinity). However, the algal-bacterial granules in $\mathrm{R} 4$ were ineffective at the removal of $\mathrm{N}$ and $\mathrm{P}$ during the treatment, although the lipid content dramatically improved by $107 \%$ when treating $4 \%$ salinity eutrophication water. Thus, the use of algal-bacterial granules for the treatment of $4 \%$ eutrophication water is not recommended. But it can still be considered when the main purpose is to extract the enhanced lipids from the waste algal-bacterial granules.

\section{CONCLUSIONS}

1. Algal-bacterial granular sludge was successfully used for the treatment of simulated salty eutrophication water with $2 \%$ salinity in the present study. A high removal rate of $\mathrm{N}$ and $\mathrm{P}$ nutrients (greater than $98 \%$ ) was observed, and the filamentous algae from the Cyanobacteria phylum played an important role in the removal process. A lipid enhancement rate of $27.6 \%$ was also obtained.

2. The algal-bacterial granules in the $4 \%$ salinity eutrophication water were inefficient at the removal of $\mathrm{N}$ and $\mathrm{P}$ nutrients. However, they led to a dramatic increase in lipid production (107\%), which showed a strong potential for biodiesel extraction processes. 


\section{ACKNOWLEDGMENTS}

The authors would like to thank the Tianjin Municipal Science and Technology Project (No. 17ZXSTSF00100) for their financial support.

\section{REFERENCES CITED}

Ahmad, J. S. M., Cai, W., Zhao, Z., Zhang, Z., Shimizu, K., Lei, Z., and Lee, D. (2017). "Stability of algal-bacterial granules in continuous-flow reactors to treat varying strength domestic wastewater," Bioresour. Technol. 244, 225-233. DOI: 10.1016/j.biortech.2017.07.134

Anahas, A. M. P., and Muralitharan, G. (2018). "Characterization of heterocystous cyanobacterial strains for biodiesel production based on fatty acid content analysis and hydrocarbon production," Energy Convers. Manage. 157, 423-437. DOI: 10.1016/j.enconman.2017.12.012

American Public Health Association (APHA) (2012). Standard Methods for the Examination of Water and Wastewater $\left(22^{\text {nd }}\right.$ Ed.), Washington, D.C.

Bhagowati, B., and Ahamad, K. U. (2018). "A review on lake eutrophication dynamics and recent developments in lake modeling," Ecohydrol. Hydrobiol. 19, 155-166. DOI: 10.1016/j.ecohyd.2018.03.002

Blaas, H., and Kroeze, C. (2014). "Possible future effects of large-scale algae cultivation for biofuels on coastal eutrophication in Europe," Sci. Total Environ. 496, 45-53. DOI: 10.1016/j.scitotenv.2014.06.131

Bora, A. P., Gupta, D. P., and Durbha, K. S. (2020). "Sewage sludge to bio-fuel: A review on the sustainable approach of transforming sewage waste to alternative fuel," Fuel 259, 116262. DOI: 10.1016/j.fuel.2019.116262

Chambers, P. A., McGoldrick, D. J., Brua, R. B., Vis, C., Culp, J. M., and Benoy, G. A. (2012). "Development of environmental thresholds for nitrogen and phosphorus in streams," J. Environ. Qual. 41, 7-20. DOI:10.2134/jeq2010.0273

Cheng, J., Feng, J., Sun, J., Huang, Y., Zhou, J., and Cen, K. (2014). "Enhancing the lipid content of the diatom Nitzschia sp. by 60Co-g irradiation mutation and high-salinity domestication," Energy 78, 9-15. DOI. 10.1016/j.energy.2014.06.009

Corrales-González, M., Rochera, C., Picazo, A., and Camacho, A. (2019). "Effect of wastewater management on phosphorus content and sedimentary fractionation in Mediterranean saline lakes," Sci. Total Environ. 668, 350-361. DOI: 10.1016/j.scitotenv.2019.02.371

Derolez, V., Bec, B., Munaron, D., Fiandrino, A., Pete, R., Simier, M., Souchu, P., Laugier, T., Aliaume, C., and Malet, N. (2019). "Recovery trajectories following the reduction of urban nutrient inputs along the eutrophication gradient in French Mediterranean lagoons," Ocean Coast Manage 171, 1-10. DOI: 10.1016/j.ocecoaman.2019.01.012

Hamza, R. A., Zaghloul, M. S., Iorhemen, O. T., Sheng, Z., and Tay, J. H. (2019). "Optimization of organics to nutrients (COD:N:P) ratio for aerobic granular sludge treating high-strength organic wastewater," Sci. Total Environ. 650, 3168-3179. DOI: 10.1016/j.scitotenv.2018.10.026 
Hu, Y., Hao, X., Loosdrecht, M. V., and Chen, H. (2017). "Enrichment of highly settleable microalgal consortia in mixed cultures for effluent polishing and low-cost biomass production," Water Res. 125, 11-22. DOI: 10.1016/j.watres.2017.08.034

Ishika, T., Moheimani, N. R., and Bahri, P. A. (2017). "Sustainable saline microalgae cocultivation for biofuel production: A critical review," Renewable Sustainable Energy Rev. 78, 356-368. DOI: 10.1016/j.rser.2017.04.110

Jorfi, S., Pourfadakari, S., and Ahmadi, M. (2017). "Electrokinetic treatment of high saline petrochemical wastewater: Evaluation and scale-up," J. Environ. Manage. 204(1), 221-229. DOI: 10.1016/j.jenvman.2017.08.058

Ju, C., Wang, F., Huang, Y., and Fang, Y. (2018). "Selective extraction of neutral lipid from wet algae paste and subsequently hydroconversion into renewable jet fuel," Renewable Energy. 118, 521-526. DOI: 10.1016/j.renene.2017.11.028

Katsuki, K., Seto, K., Tsujimoto, A., Takata, H., and Sonoda, T. (2019). "Relationship between regional climate change and primary ecosystem characteristics in a lagoon undergoing anthropogenic eutrophication, Lake Mokoto, Japan," Estuarine Coastal Shelf Sci. 222, 205-213. DOI: 10.1016/j.ecss.2019.04.016

Liu, L., Fan, H. Y., Liu, Y. H., Liu, C. X., and Huang, X. (2017). "Development of algaebacteria granular consortia in photo-sequencing batch reactor," Bioresour. Technol. 232, 64-71. DOI: 10.1016/j.biortech.2017.02.025

Longley, K. R., Huang, W., Clark, C., and Johnson, E. (2019). "Effects of nutrient load from St. Jones River on water quality and eutrophication in Lake George, Florida," Limnologica 77, 125687. DOI: 10.1016/j.limno.2019.125687

Luo, J., Zhang, Q., Zhao, J., Wu, Y., Wu, L., Li, H., Tang, M., Sun, Y., Guo, W., Feng, Q., Cao, J., and Wang, D. (2020). "Potential influences of exogenous pollutants occurred in waste activated sludge on anaerobic digestion: A review," J. Hazard. Mater. 383, 121176. DOI: 10.1016/j.jhazmat.2019.121176

Manolidi, K., Triantis, T. M., Kaloudis, T., and Hiskia, A. (2019). "Neurotoxin BMAA and its isomeric amino acids in cyanobacteria and cyanobacteria-based food supplements," J. Hazard. Mater. 365, 346-365. DOI: 10.1016/j.jhazmat.2018.10.084

McIver, R., Cullain, N., Schmidt, A. L., and Lotze, H. K. (2018). "Linking eutrophication indicators in eelgrass habitats to nitrogen loading and mitigating site characteristics in eastern New Brunswick, Canada," Mar. Environ. Res. 144, 141-153. DOI: 10.1016/j.marenvres.2018.11.013

Meng, F., Liu, D., Huang, W., Lei, Z., and Zhang, Z. (2019a). "Effect of salinity on granulation, performance and lipid accumulation of algal-bacterial granular sludge," Bioresour. Technol. Rep. 7, 100228. DOI: 10.1016/j.biteb.2019.100228

Meng, F., Xi, L., Liu, D., Huang, W., Lei, Z., Zhang, Z., and Huang, W. (2019b). "Effects of light intensity on oxygen distribution, lipid production and biological community of algal-bacterial granules in photo-sequencing batch reactors," Bioresour. Technol. 272, 473-481. DOI: 10.1016/j.biortech.2018.10.059

Shi, Z., Zhao, B., Tang, S., and Yang, X. (2018). "Hydrotreating lipids for aviation biofuels derived from extraction of wet and dry algae," J. Cleaner Prod. 204, 96-915. DOI: $10.1016 /$ j.jclepro.2018.08.351

Tyagi, V. K., and Lo, S. -L. (2013). "Sludge: A waste or renewable source for energy and resources recovery?" Renewable Sustainable Energy Rev. 25, 708-728. DOI: 10.1016/j.rser.2013.05.029 
Vinçon-Leite, B., and Casenave, C. (2019). "Modelling eutrophication in lake ecosystems: A review," Sci. Total Environ. 651, 2985-3001. DOI: 10.1016/j.scitotenv.2018.09.320

Vo Hoang Nhat, P., Ngo, H. H., Guo, W. S., Chang, S. W., Nguyen, D. D., Nguyen, P. D., Bui, X. T., Zhang, X. B., and Guo, J. B. (2018). "Can algae-based technologies be an affordable green process for biofuel production and wastewater remediation?" Bioresour. Technol. 256, 491-501. DOI: 10.1016/j.biortech.2018.02.031

Xiong, J., Wang, X. C., Zhang, Q., Duan, R., and Wang, N. (2016). "Characteristics of a landscape water with high salinity in a coastal city of China and measures for eutrophication control," Ecol. Indic. 61, 268-273. DOI:

10.1016/j.ecolind.2015.09.026

Yang, G., Zhang, G., and Wang, H. (2015). "Current state of sludge production, management, treatment and disposal in China," Water Res. 78, 60-73. DOI: 10.1016/j.watres.2015.04.002

Yao, J., Wang, G., Xue, B., Wang, P., Hao, F., Xie, G., and Peng, Y. (2019). "Assessment of lake eutrophication using a novel multidimensional similarity cloud model,” J. Environ. Manage. 248, 109259. DOI: 10.1016/j.jenvman.2019.109259

Zhang, L., Pei, H., Chen, S., Jiang, L., Hou, Q., Yang, Z., and Yu, Z. (2018). "Salinityinduced cellular cross-talk in carbon partitioning reveals starch-to-lipid biosynthesis switching in low-starch freshwater algae," Bioresour. Technol. 250, 449-456. DOI: 10.1016/j.biortech.2017.11.067

Zhang, W., Zhang, Z., Wang, Y., Ai, D., Wen, P., Zhu, Y., Cao, L., and Yao, T. (2017). "Effect of turfgrass establishment on soil microbiota using Illumina Sequencing," Nat. Environ. Pollut. Technol. 16, 679-686.

Zhang, Z., Zhou, Y., Zhang, J., Xia, S., and Hermanowicz, S. W. (2016). "Effects of short-time aerobic digestion on extracellular polymeric substances and sludge features of waste activated sludge," Chem. Eng. J. 299, 177-183. DOI: 10.1016/j.cej.2016.04.047

Zhao, Z., Liu, S., Yang, X., Lei, Z., Shimizu, K., Zhang, Z., Lee, D., and Adachi, Y. (2019). "Stability and performance of algal-bacterial granular sludge in shaking photo-sequencing batch reactors with special focus on phosphorus accumulation," Bioresour. Technol. 280, 497-501. DOI: 10.1016/j.biortech.2019.02.071

Zheng, X., Jin, M., Zhou, X., Chen, W., Lu, D., Zhang, Y., and Shao, X. (2019). "Enhanced removal mechanism of iron carbon micro-electrolysis constructed wetland on $\mathrm{C}, \mathrm{N}$, and $\mathrm{P}$ in salty permitted effluent of wastewater treatment plant," Sci. Total Environ. 649, 21-30. DOI: 10.1016/j.scitotenv.2018.08.195

Zhou, Y., Zhang, J., Zhang, Z., Wang, P., and Xia, S. (2019). "pH dependent of the waste activated sludge reduction by short-time aerobic digestion (STAD) process," Sci. Total Environ. 649, 1307-1313. DOI: 10.1016/j.scitotenv.2018.08.41

Article submitted: July 11, 2019; Peer review completed: September 8, 2019; Revised version received and accepted: October 13, 2019; Published: October 16, 2019. DOI: 10.15376/biores.14.4.9518-9530 


\section{SUPPLEMENTAL INFORMATION}

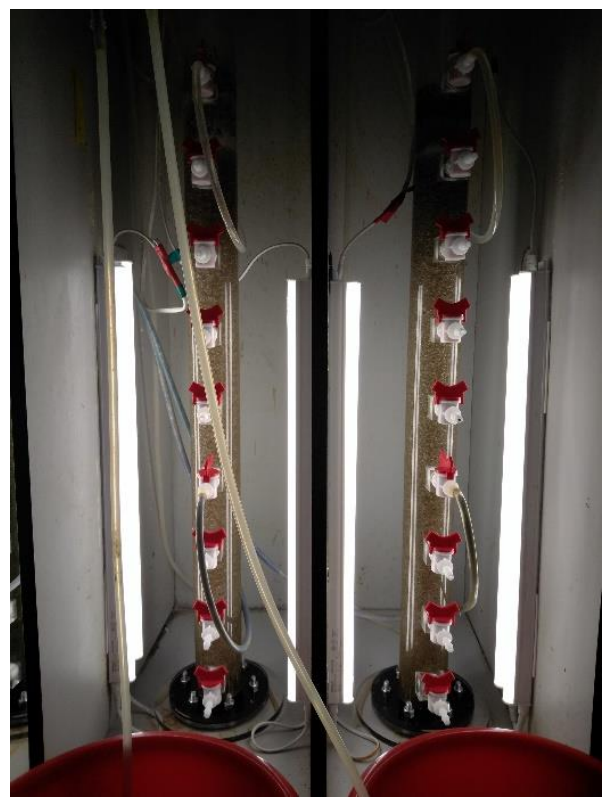

Fig. S1. Photo-sequencing batch reactors

(a)

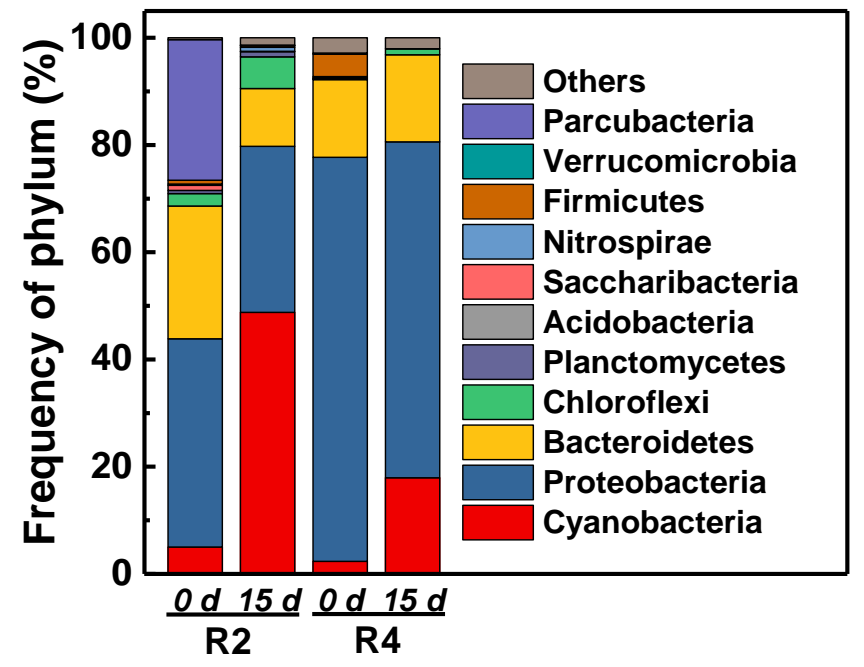




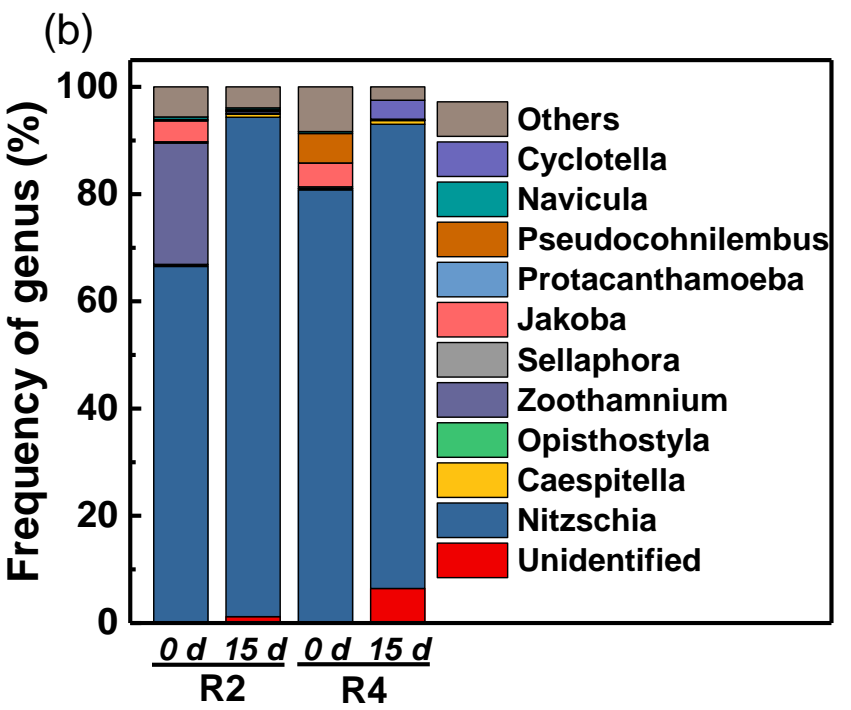

Fig. S2. Abundance of dominant prokaryotes at the phylum level (a) and eukaryotes at the genus level (b) in the granules of the two reactors at $0 \mathrm{~d}$ and at $15 \mathrm{~d}$.

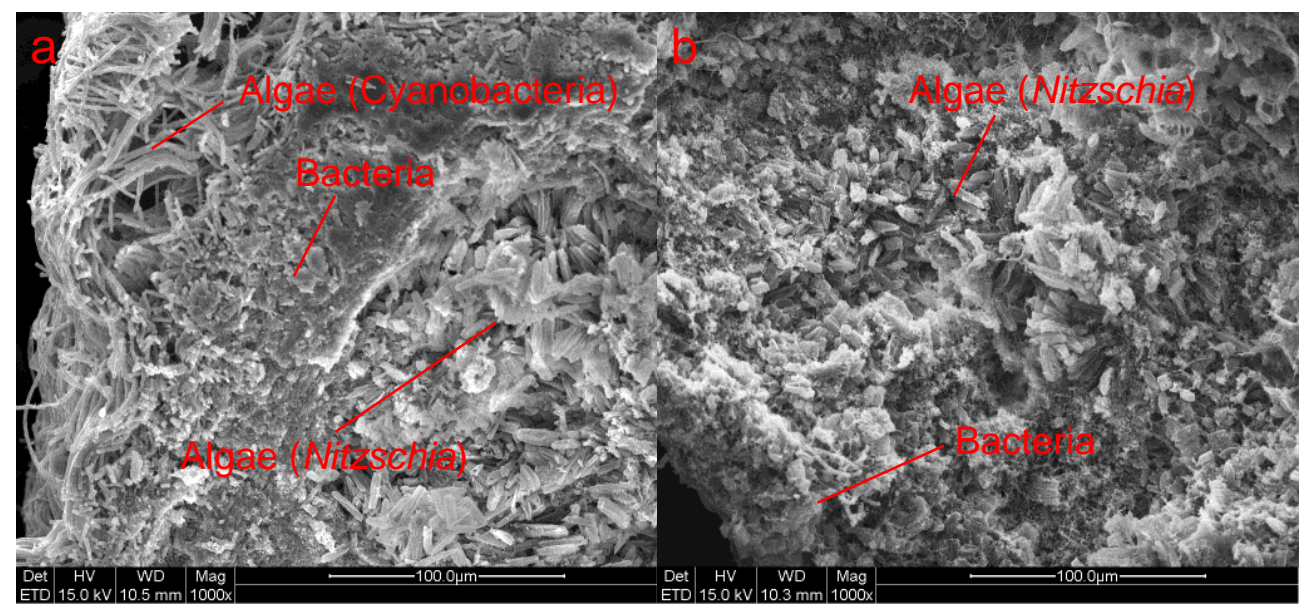

Fig. S3. SEM images for the cross section of granules from R2 (a) and R4 (b) at $15 \mathrm{~d}$. 